JIME (Journal of Industrial and Manufacture Engineering), 3 (1) Mei 2019 ISSN 2549-6328 (Print) ISSN2549-6336 (Online)

JIME (Journal of Industrial and Manufacture Engineering)

Available online http://ojs.uma.ac.id/index.php/jime

Email: jime@uma.ac.id

\title{
Peningkatan Hasil Belajar Kimia Siswa pada Pokok Bahasan Sistem Koloid Menggunakan Buku Ajar Kimia Inovatifproject Based Learning (PJBL)
}

\author{
Leny Novita*1) \& Kasrawati ${ }^{2)}$ \\ Jurusan Kimia, Fakultas Sain Teknologi dan Informasi, Universitas Sari Mutiara \\ Indonesia $^{1)}$ \& Akademi Teknik Indonesia Cut Meutia' ${ }^{2)}$, Indonesia \\ Diterima: April 2019; Disetujui: Mei 2019; Dipublikasi: Mei 2019; \\ * Corresponding author: lenynovita8@gmail.com
}

\begin{abstract}
Abstrak
The development of paradigm for the human resources potential needed indemandsin all areas, notjustthe qualityof human resources, buthumancharacteritself. Teaching innovations incorporated into textbooks is expected to enhance thequality of education and develop the character building ofthe nation's generation. This research aims to know learners gain optimal learning results. The population is allhigh schools in North Sumatra. The sampleinthis study were used research and development methodand taken by purposive sampling, namely SMA Hang Tuah Belawan, SMAN 9 Medan and SMAN 19 Medan each as much as 2 classes. Experiment and Control Class. Data were analyzed by using independent sample t-test with SPSS 20 for windowsat significance level 0.05. Results showed that innovative chemistry textbook has been successfully improved the student learning out comes. Innovative textbook can be used to transform the original teacher centered learning into a student centered learning.
\end{abstract}

Keywords : innovative textbook of Chemistry, the PJBL model, learners, senior high school

How to Cite: Leny Novita \& Karaswati (2019). Peningkatan Hasil Belajar Kimia Siswa Pada Pokok Bahasan Sistem Koloid Menggunakan Buku Ajar Kimia Inovatifproject Based Learning (PJBL), JIME (Journal of Industrial and Manufacture Engineering),3(1): 26-32 


\section{PENDAHULUAN}

Dewasa ini kriteria mengenai potensi lulusan yang dibutuhkan di dunia kerja dengan berbagai peran/jabatannya di lembaga bisnis maupun industri telah cenderung merubah paradigm mengenai potensi sumber daya manusia (Silalahi, 2013). Salah satu usaha pemerintah untuk meningkatkan kualitas kompetensi lulusan di Indonesia menerapkan kurikulum 2013.

Pada kurikulum 2013, terdapat kelompok mata pelajaran peminatan yang diikuti oleh peserta didik sesuai bakat, minat dan kemampuannya. Kimia merupakan salah satu mata pelajaran peminatan di SMA/MA (Kemendikbud, 2013). Namun dalam mengajarkan kimia di sekolah banyak ditemui hambatan.

Hasil penelitian Mustofa (2010) menunjukkan bahwa kemampuan siswa kelas XI IPA SMA Negeri 3 Mojokerto dalam menyelesaikan soal-soal konseptual dan soal-soal algoritmik pada materi larutan asam-basa, buffer, dan larutan garam termasuk dalam kategori rendah. Selanjutnya penelitian Amarlita (2010) pada SMA Negeri 1 Bontang juga menemukan terdapat banyak kesalahan konsep pada siswa kelas XI dalam mempelajari konsep materi Laju Reaksi. Khodryah (2010) juga menemukan kesalahan-kesalahan konsep yang terjadi pada siswa SMA kelas XI SMA Negeri 2
Bontang dan SMA YPK Bontang pada materi larutan buffer.

Beberapa faktor penyebab kurangnya penguasaan materi kimia bagi siswa SMA/MA diantaranya adalah: sistematika dan urutan materi pelajaran yang belum mampu memotivasi siswa belajar karena mengajarkan materi pelajaran yang tergolong sulit tanpa memberikan pengertian dasar yang diperlukan, (2) siswa sering belajar dengan cara menghafal tanpa membentuk pengertian terhadap materi kimia yang dipelajari, (3) materi pelajaran yang diajarkan mengambang sehingga siswa tidak dapat menemukan 'kunci' untuk mengerti pelajaran yang sedang dipelajari, dan (4) guru tertentu kurang berhasil menyampaikan konsep bagi siswa untuk menguasai materi pelajaran karena kurangnya penguasaan metode pembelajaran (Situmorang, 2004).

Simatupang, dkk (2013) menyatakan bahwa salah satu upaya meningkatkan pemahaman dan kompetensi lulusan terhadap kimia adalah dengan menyediakan fasilitas belajar. Terkait dengan fasilitas belajar, buku pelajaran merupakan salah satu akses pendidikan yang penting dalam menyelenggarakan pendidikan nasional. Buku ajar yang baik tentu saja harus mampu memotivasi siswa untuk belajar. 
Leny Novita \& Karaswati, Peningkatan Hasil Belajar Kimia Siswa pada Pokok Bahasan Sistem Koloid Menggunakan Buku Ajar Kimia Inovatifproject Based Learning (PJBL)

Penelitian mengenai kegunaan meningkatkan mutu pendidikan dan sumber media belajar dalam pengajaran bahasa Inggris oleh Makewa, dkk (2012) menunjukkan bahwa umber media tersebut berguna dalam pengajaran bahasa Inggris, baik siswa laki-laki dan siswa perempuan setuju bahwa media belajar berguna dalam pengajaran bahasa Inggris. Oleh karena itu sangat penting bagi sekolah menengah untuk menyediakan bahan yang memadai dan relevan untuk pengajaran dan pembelajaran, tidak hanya bahasa Inggris, tetapi untuk semua mata pelajaran lain dalam kurikulum sekolah menengah.

Selama ini proses pembelajaran masih menggunakan bahan ajar berupa buku teks, maka disarankan agar menggunakan buku yang lebih aplikatif dalam proses pembelajaran sehingga dapat membantu siswa untuk dapat memahami materi pembelajaran dan siswa mampu mengaitkan pembelajaran yang diperoleh dengan kehidupan nyata sehingga tidak hanya memperoleh nilai yang memuaskan di kelas tetapi siswa juga mampu mengaplikasikan ilmu yang diperoleh dalam kehidupannya (Harahap, 2013). Agar buku teks yang digunakan dapat lebih aplikatif dan inovatif maka dapat disusun materi yang dapat membuat siswa aktif belajar.

Inovasi pembelajaran dan integrasi pendidikan karakter di dalambuku ajar akan dapat memberi peluang mengembangkan karakter bangsa sesuai dengan budaya di Indonesia (Situmorang,2013). Inovasi pembelajaran untuk meningkatkan prestasi belajar siswa pada materi pelajaran kimia sangat perlu dilakukan karena berhubungan dengan peningkatan kualitas lulusan dalam mengisi lapangan kerja bidang kimia (Matchmes,dkk, 2009). Pemanfaaatan teknologi informasi untuk pembelajaran juga telah mendorong pergeseran pembelajaran dari pembelajaran konvensional kepada pembelajaran mandiri sehingga kesan pembelajaran diingat oleh siswa (Tompkins, 2006).

Narayanan dan Adithan menyatakan bahwa mahasiswa (siswa) saat ini adalah pelajar aktif. Model pembelajaran tradisional dimana pembelajaran berpusat pada guru tidak bias lagi digunakan saat ini (Suharta dan Luthan, 2013). Perlu adanya suasana yang baru dalam kegiatan pembelajaran kimia yang diharapkan mampu secara materi dan dapat membuat siswa menjadi aktif dalam pembelajaran, sehingga mampu meningkatkan prestasi belajar siswa (Siregar dan Parera, 2013).

Salah satu model pembelajaran yang dapat digunakan dalam pembelajaran siswa aktif yaitu model pembelajaran Project Based Learning (PjBL). Telah banyak dilakukan penelitian yang berhubungan dengan 
model pembelajaran PjBL yang pada kesimpulannya dapat meningkatkan kreativitas dan aktivitas siswa.

Pada penelitian mengenai pembelajaran berbasis proyek oleh Mihardi, dkk (2013) menunjukkan bahwa pemikiran kreatif siswa pada model pembelajaran berbasis proyek lebih besar dari pada model pembelajaran kooperatif. Ini terbukti proses pembelajaran dengan model pembelajaran berbasis proyek efektif dalam memajukan proses berpikir kreatif siswa dan pengamatan yang dilakukan oleh pengamat menunjukkan bahwa aktivitas siswa meningkat secara positif.

Selanjutnya hasil penelitian mengenai efek metode pembelajaran berbasis proyek menunjukkan bahwa metode pembelajaran ini efektif mengembangkan keterampilan proses ilmiah mahasiswa (Ozer dan Ozkan, 2013). Rohendi dan Dulpaja (2013) juga menyatakan bahwa aktivitas siswa dalam proses pembelajaran dengan menggunakan proyek matematika terhubung berdasarkan media presentasi benar-benar meningkat secara positif dan mereka belajar dengan sangat aktif.

\section{METODE PENELITIAN}

Penelitian ini merupakan penelitian pengembangan Borg dan Gall yang telah dimodifikasi sesuai kebutuhan. Penelitian dilakukan pada bulan Mei-Agustus 2014 di SMA Hang Tuah Belawan, SMA Negeri 9 Medan, dan SMA Negeri 19 Medan. Sampel dipilih secara purposive sampling. Penelitian menggunakan 2 kelas ditiap sekolah. Dimana kelas pertama sebagai kelas eksperimen dengan menggunakan buku ajar kimia inovatifyang telah terstandarisasi oleh validator ahli dan kelas kedua sebagai kelas kontrol tanpa menggunakan buku ajar kimia inovatif.

Instrumen yang digunakan adalah test kognitif yang sudah terstandar.Tahapan penelitian terdiri atas (1) Pengambilan nilai pre test dilakukan sebelum proses belajar mengajar menggunakan buku ajar, (2) Penggunaan buku ajar untuk meningkatkan hasil belajar kimia pada siswa SMA, dan Pengambilan nilai post test setelah menggunakan buku ajar.

Data hasil belajar diperoleh melalui aplikasi buku ajar kmia inovatif untuk pembelajaran sistem koloid pada siswa SMA. Evaluasi pendahuluan (pretest) dilakukan sebelum pembelajaran, evaluasi akhir (Posttest) dilakukan setelah selesai proses pembelajaran selesai. Untuk analisis data hasil belajar siswa dilakukan uji normalitas dengan uji KolmogorofSmirnov Test menggunakan SPSS 20 pada sig. > ? $(0,05)$. Untuk mengetahui apakah data yang telah dikumpulkan berdistribusi normal atau berasal dari populasi yang 
Leny Novita \& Karaswati, Peningkatan Hasil Belajar Kimia Siswa pada Pokok Bahasan Sistem Koloid Menggunakan Buku Ajar Kimia Inovatifproject Based Learning (PJBL)

bervarians sama (homogen) digunakan uji homogenitas varians (Levene's test).

Pengujian hipotesis dilakukan dengan menggunakan uji independent sample t-test pada taraf signifikansi 0 0,05 dengan SPSS 20.

\section{HASIL DAN PEMBAHASAN}

Berdasarkan proses pelaksanaan penelitian ini, mulai dari pengambilan nilai pre test, implementasi buku ajar inovatif pada siswa SMA, dan pengumpulan data hingga analisisnya dapat dipaparkan beberapa hal berikut ini.

1.1. Penggunaan buku ajar kimia inovatif dalam pembelajaran kimia.

Buku ajar kimia inovatif dijadikan sebagai bahan ajar pada pengajaran kimia pokok bahasan sistem koloid pada kelompok eksperimen, dan sebagai pembanding dipergunakan buku ajar pegangan siswa padakelas kontrol. Sebelum pembelajaran dilakukan, penguasaan siswa terhadap sistem koloid dievaluasi seperti dirangkum pada tabel 1. Hasil pretest berfungsi untuk membebaskan outlier sehingga yang dipergunakan dalam penelitian adalah siswa SMA yang memiliki kemampuan akademik relatif sama.
Tabel1.Hasil Uji Normalitas, Homogenitas

Pretes, Postesdan Gain

\begin{tabular}{cccccccc}
\hline No & Data & $\begin{array}{c}\text { Kolmogorof- } \\
\text { Smimov Z }\end{array}$ & Sig. & Ket & $\begin{array}{c}\text { Levene's } \\
\text { Test F }\end{array}$ & Sig. & Ket \\
\hline 1 & Pretes & 1,33 & 0,058 & Normal & 0,003 & 0,957 & Homogen \\
2 & Postes & 1,302 & 0,067 & Normal & 0,071 & 0,791 & Homogen \\
3 & Gain & 0,709 & 0,696 & Normal & 0,43 & 0,513 & Homogen \\
\hline
\end{tabular}

Hasil analisis menunjukkan bahwa responden yang diikutkan dalam penelitian ini bersifat homogen(sig. 0,957 > 0,05) danberdistribusi normal (sig. 0,058 > 0,05). Dari uji peningkatan hasil belajar kimia siswa diperoleh peningkatan hasil belajar kimia siswa terhadap penguasaan konsep materi pada pokok bahasan sistem koloid untuk kedua kelas. Dimana pada kelas eksperimen menggunakan buku ajar kimia inovatif hasil pengembangan sebesar 59\% dan kelas kontrol menggunakan buku ajar pegangan siswa sebesar 49\%.Histogram nilai gain dapat dilihat pada gambar berikut.

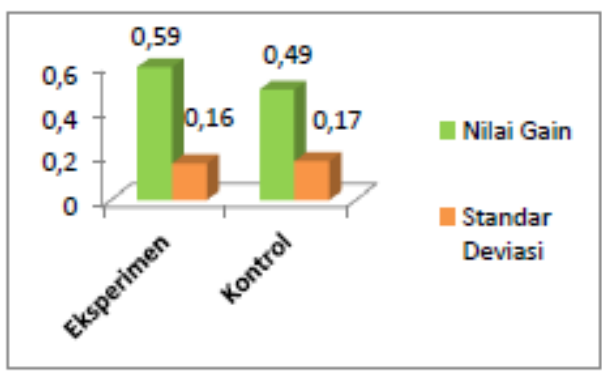

\section{Gambar 1. Histogram nilai gain kelas eksperimen dan kelas kontrol}

Hal ini disebabkan karena buku kimia inovatif memiliki isi yang menarik sehingga dapat mendorong siswa untuk belajar mandiri. Contoh soal yang tersedia di dalam buku seperti kimia makanan 


menjadikan siswa belajar kimia
itensifsehingga $\quad$ efektif
meningkatkan hasil belajar siswa
pengajaran sistem koloid.

\section{SIMPULAN}

\section{Peningkatan hasil belajar kimia}

siswa pada pokok bahasan system koloid pada kelas eksperimen (59\%) lebih tinggi di bandingkan kelas kontrol (49\%).

\section{DAFTAR PUSTAKA}

Amarlita.D.M., (2010).Identifikasi Kesalahan Konsep Materi Laju Reaksi pada Siswa Kelas XI SMA Negeri 1 Pagakdan Perbaikannya dengan Menggunakan Strategi Konflik Kognitif, Program Studi Pendidikan Kimia. Program Pascasarjana, Universitas Negeri Malang

Ahyan,S., (2012), Penelitian Pengembangan dalam Pendidikan, www.yekamath.wordpress.comakses Februari 2014

Harahap, S.J., (2013), Pengembangan Buku Ajar Bioteknologi SMA Berbasis Literasi Sains, Program Pascasarjana Universitas Negeri Medan, Medan

Kemendikbud, (2013), Kurikulum 2013, Kompetensi Dasar Sekolah Menengah Atas (SMA)/ Madrasah Aliyah(MA), Kementrian Pendidikan dan Kebudayaan, Jakarta

Khodaryah. N., (2010), Analisis Kesalahan Konsep Tentang Larutan Buffer Pada Siswa Kelas XI IPA SMAN 2 dan SMA YPK Bontang Serta Upaya Memperbaikinya dengan Menggunakan Strategi Konflik Kognitif, Program Studi Pendidikan Kimia. Program Pascasarjana, UniversitasNegeri Malang

Makewa, L.N., Role, E., dan Ngussa, B., (2012), Usefulness of Media Resources in English Instruction: A Case of Adventist Secondary Schools in Tanzania, Journal of Education and Practice3(15): 163-172

Matchmes, K., Johnson, E., Fox, J. Dan Burke, M.S., (2009) Teaching Qualitative Research Methods through Service-Learning, The Qualitative Report4(1): 155-165

Mihardi, S., Harahap, M.B., dan Sani, R.A., (2013), The Effect of Project Based Learning Model with KWL Worksheet on Student Creative Thinking Process in Physics Problems, Journal of Education and Practice4(25): 188200
Mustofa, (2010) Analisis Pemahaman Konseptual dan Pemahaman Algoritmik Materi Larutan Asam-Basa, Buffer dan Larutan Garam Siswa Kelas XI SMAN 3 Mojokerto serta Upaya Perbaikannya dengan Pendekatan Mikroskopik, Program Studi Pendidikan Kimia. Program Pascasarjana. Universitas Negeri Malang

Narayanan, S., dan Adithan, M., (2012), Alternative Learning Approaches for Enhanced Students' Engagement in Engineering Courses, Journal of Education and Practice3(15): 27-37

Özer, D.Z., dan Özkan, M., (2013), The Effect of Project Based Learning Method on Science Process Skills of Prospective Teachers of Science Education in Biology Lessons,International Online Journal of Educational Sciences, 5(3): 635-645

Rohendi, D., dan Dulpaja, J., (2013), Connected Mathematics Project (CMP) Model Based on Presentation Media to the Mathematical Connection Ability of Junior High School Student, Journal of Education and Practice, 4(4): 17-22

Silalahi, A., (2013), Penerapan Model Contextual Instruction yang Merupakan Industrial Practice dalam Pembelajaran Kimia Sangat Rasional Menumbuhkembangkan Soft Skills Peserta Didik, Jurnal Pendidikan Kimia, 5(2): 129-131

Simatupang, N.I., Situmorang, M., dan Silaban, R., (2013), Pengembangan Buku Ajar Kimia Inovatif untuk SMA/MA kelas X Semester II, Jurnal Pendidikan Kimia, 5(2): 83-90

Siregar, T., dan Parera, T.V., (2013), Perbedaan Hasil Belajar Kimia Menggunakan Pembelajaran Tipe Think Pair Share (TPS) dengan Tipe Numbered Heads Together (NHT) di SMA YPPK Teruna Bakti Waena Jayapura, Jurnal Pendidikan Kimia, 5(2): 77-82

Situmorang, M., (2004), Inovasi Model-model Pembelajaran Bidang Sains untuk Meningkatkan Prestasi Belajar Mahasiswa, Prosiding Konaspi V Surabaya tahun 2004, http://prosiding.unesa.ac.id/download/kon aspi-unesa-v/146.pdf

Situmorang, (2013), Pengembangan Buku Ajar Kimia SMA Melalui Inovasi Pembelajaran Dan Integrasi Pendidikan Karakter Untuk Meningkatkan Hasil Belajar Siswa,Universitas Negeri Medan, Medan.

Situmorang, M., Retno,D.W., dan Sri, M, (2013), Pengembangan Buku Ajar Kimia SMA/MA MelaluiInovasi Pembelajaran dan Integrasi Pendidikan Karakter, Prosiding Seminar Hasil Lembaga Penelitian Unimed, 1-8

SuhartadanLuthan, P.L.A., (2013), Pengembangan Model Pembelajaran dan Penyusuan Bahan Ajar dengan pendekatan PAKEM PLUS untuk Meningkatkan Hasil Belajar dan Menumbuh kembangkan Karakter Mulia Siswa dalam 
Leny Novita \& Karaswati, Peningkatan Hasil Belajar Kimia Siswa pada Pokok Bahasan Sistem Koloid Menggunakan Buku Ajar Kimia Inovatifproject Based Learning (PJBL)

Pelajaran Kimia di SMA, UniversitasNegeri Medan, Medan.

Suharta, dan Luthan P.L.A., (2013), Application of Cooperative Problem-Based Learning Model to Develop Creativity and Foster Democracy, and Improve Student Learning Outcomes in Chemistry in High School, Journal of Education and Practice, 4(25): 55-60
Tompkins, C.J., Rosen, A.L., dan Larkin, H., (2006), Guest Editorial: An Analysis of Social Work Textbooks for Aging content: How Well do Social Work Foundation Texts Prepare Students for Our Aging Society?, Journal of Social Work Education42(1): 3-2 